Available online at: https://journals.researchsynergypress.com/index.php/ijtaese

International Journal of Theory and Application in Elementary and Secondary School Education

(IJTAESE)

ISSN 2684-7167 (online)

Volume 3 Number 1 (2021): 74-81

\title{
A Bibliometric Analysis of E-Learning Research Trends
}

\author{
Regina Deti ${ }^{1}$, Virginia Mandasari ${ }^{2}$ \\ ${ }^{1}$ Universitas Katolik Parahyangan, Indonesia \\ ${ }^{2}$ UPN Veteran Jawa Timur, Indonesia
}

\begin{abstract}
The teaching and learning process as if there must always be an increase in effectiveness in order to achieve the goals to be achieved. The development of the world of information technology has now become so fast and has penetrated various sides of human life. The use of information technology such as elearning, one of which is through web-based learning, will bring significant changes both in terms of the education system to be developed, the material to be delivered, how the instructional and learning processes will be carried out, and the obstacles that will be faced either by the education recipient and the educators. This research uses bibliometric analysis to map how e-learning is intended from several previous journals using vosviewer. This research concludes that e-learning is unavoidable, especially in the industrial era 4.0, where e-learning is believed that education can be accessed anytime, anywhere, and by anyone.
\end{abstract}

Keywords: e-learning; online learning; training; bibliometric; vos viewer

This is an open access article under the CC-BY-NC license.

\section{INTRODUCTION}

Effectiveness is a learning process carried out by educators to change the abilities and perceptions of education recipient from having difficulty learning something to easy learning it (Suyanto and Jihad, 2013). The effectiveness of learning can be interpreted as the achievement of learning objectives that have been determined by the educators through a model that has been determined in each process learning (Wibowo and Roysa, 2018). The teaching and learning process as if there must always be an increase in effectiveness in order to achieve the goals to be achieved. Therefore, to increase the effectiveness of learning without having to waste a lot of time or energy, an educator is required to be clever in choosing the learning model that should be used with the aim that students understand what is being taught.

The World Bank conducted a survey in 2010 indicating a mismatch of skills with the education mastered, a world bank survey showed that $80 \%$ of companies had difficulty filling managerial positions, and $60 \%$ had difficulty filling professional positions. It was also found that only $44 \%$ of English skills could be mastered, $41 \%$ leadership, $36 \%$ computer skills, 35\% cooperation skills, 33\% communication, and $33 \%$ high-order thinking skills. In addition, the company also found that $18 \%$ practical knowledge and $18 \%$ theoretical knowledge were related to their work.

Paying attention to these data, shows that the development of existing technology has not been fully utilized in the world of education, so that it will have an impact on the weakness of skills in learning and innovation, and skills in using technology and information media.

The learning program is the most important process because this is where there is direct interaction between educators and students. The development of the world of information technology has now become so fast and has penetrated various sides of human life. The development of information 
technology has a huge impact on various sides of life, from government, administration, economy, education, and others. In the field of economic sector some people may already be familiar with what is called e-commerce, e-business, e-marketing. While in the government, nowadays the term e-government is starting to be known. Likewise, in the field of education, many have started to use information technology to convey learning in its popular term, namely e-learning. Such developments are supported by the availability of hardware and software which are increasingly capable of becoming increasingly powerful.

E-learning is an effective learning process that is produced by combining digital material delivery consisting of support and services in learning (Suharyanto and Mailangkay, 2016). The use of information technology such as e-learning, one of which is through web-based learning, will bring significant changes both in terms of the education system to be developed, the material to be delivered, how the instructional and learning processes will be carried out, and the obstacles that will be faced either by the education recipient and the educators.

The ILRT of Bristol University (in Tamin, 2013) defines E-learning as the use of electronic technology to deliver, support and enhance teaching, learning and assessment. The use of this method must also be supported by the existence of a network to connect users to one another, as stated by Purbo and Hartanto (2002), that E-learning is used as a term for all technologies used to support teaching efforts via internet technology.

The concept of E-learning by utilizing internet technology has a lot of information and learning resources as well as facilities that are capable of supporting learning such as forums, video tutorials, tests and others that can be used to discuss material and questions and answers between educators and education recipients, download and upload. teaching materials, and others. The application of E-learning in education provides many variations in implementing learning. With this, it is hoped that the learning carried out will not be monotonous and be able to motivate students to learn. E-learning itself can function properly and in accordance with its objectives if the facilities and infrastructure used are adequate. Not only that, of course the support from E-learning users also affects the success of using this method.

The use of e-learning as technology also requires a design in order to carry out learning effectively (Islamiyah and Widayanti, 2016). The use of media such as e-learning in a learning process is expected to be an alternative to solve the problem of independent learning that is often encountered, because the use of this media allows teaching to seek and research broader knowledge in the internet world so that it raises creativity in learning science. In addition, with e-learning learning, it is also expected that the cognitive towards learning outcomes can be easily achieved.

For the world of education, E-learning is a solution and a potential in improving the quality of learning, but in making Elearning itself is not easy and requires a long time. How the views of some research on e-learning will be discussed and compared in this research. This research will use the vos viewer for mapping and clustering.

\section{RESEARCH METHOD}

Bibliometric analysis or methods are sometimes referred to as scientometrics as part of the research evaluation methodology, and from the various literature that has been produced, it is possible to carry out bibliometric analysis using a separate method (Ellegaard \& Wallin, 2015). The bibliometric method is a method of measuring the literature using a statistical approach so that it includes the application of quantitative analysis. Research using the bibliometric method can also reveal the fact that there are very few research results that are not cited after a decade of publication in popular radiology 
journals in the United States, given that citations reflect the impact of research, the results show that these journals have performed well in choosing meaningful research results, therefore it is hoped that researchers will consider these characteristics (Rosenkrantz, Chung, \& Duszak, 2019).

Bibliometric mapping will benefit both the scientific community and the general public because it can help convert publication metadata into maps or visualizations, which are easier to manage for processing in order to gain useful insights, for example visualizing keywords to identify research themes or clusters in a particular discipline, mapping author affiliations of a particular journal to identify the geographic scope of the journal, and mapping institutional collaboration and international collaboration as part of the framework for identifying emerging technologies (Tanudjaja \& Kow, 2018).

The search for literature reviews, especially journals and articles, was carried out without limiting the time of publication and used keywords including "e-learning", "digital learning" and "online learning" which were identified based on the relevance of journal content and topic linkages through Google Scholar. After the journals and articles are collected, a number of articles that have been obtained are grouped based on the relevance of the topic regarding e-learning. Although searches for journals and articles are not limited to the year they were published, journals and articles with the latest year's edition will be prioritized as the most recent studies.

Based on the search, it was found that 2030 journals were relevant and in accordance with the topic of discussion, which was then analyzed using the vosviewer. In addition, these journals are used to discuss and compare research according to topics based on their relevance. Then the journals that have been grouped will be analyzed for their explanations and compared their relationships according to the results obtained on the vosviewer.

\section{BIBLIOMETRIC ANALYSIS}

As the prefix, to see how the mapping is related to e-learning, we are looking for journals related to e-learning. We entered several keywords that are closely related to e-learning, including online learning and digital learning. We include related keywords both in the title and in the discussion of the research, both in the introduction, discussion, and conclusion. From there we found 2030 journals related to elearning. The relationship between keywords is determined based on the number of articles in which the keywords appear together (Eck \& Waltman, 2010). Keywords will expand in relation to one another.

Next, we will sort the journals that have been obtained by sorting the author's name along with the year with Microsoft Excel help, which can make it easier to detect duplication of filtered journals. We manually delete the same journal. However, we still include journals with the same author as long as they are presented with different titles and published for further mapping using the help of the vos viewer.

Leydesdorff and Rafols (2011, in Tupan and Rachmawati 2018) further explain that the results of bibliometric analysis can be visualized using several program applications such as Bibexcel, Pajek, Gephi and VOSviewer. In this research using the VOSviewer bibliometric application. This application can display publication maps in a variety of ways and functions that are more detailed, can present and present specific information about bibliometric graphic maps (Tupan et al., 2018). Through VOSviewer, large bibliometric maps can be displayed in an easy way to interpret a relationship (Eck and Waltman, 2010). In addition, it can also visualize and explore knowledge maps through databases obtained from the Web of science, Scopus, PubMed, RIS, CrossrefjSON and CrossresAPI. The online database used in this research is the database of scientific articles indexed in Scopus.

Scopus is a highly reputable international indexing database containing the largest collection of literature summaries in the world, with citations that provide bibliographies of articles and more than 
22,000 quality abstracts from peer-reviewed and published scientific and research literature. by more than 5,000 publishers worldwide and covering a wide range of knowledge areas (Elsevier BV, 21015). Scopus bibliometric capabilities can help researchers effectively track, analyze and visualize a research. Another advantage of Scopus is that it can display a system of relationships between articles and publications as well as collaboration between authors.

\section{Co-citation analysis}

Co-citation analysis is useful for mapping the specialization of research subjects, the single-link cluster method is applied for grouping co-cited articles. If all the topics covered by the data set can be identified by grouping the co-citation only partially it can be answered by comparing the results for different threshold sets of (normalized) co-citation power as some areas of research may not have consensual references. However, the findings suggest that co-citation clustering reflects research specialization, although this can be divided into several groups. It was also found that co-citation clustering only revealed a portion of the literature relevant to the research topic identified from the cited literature and that inter-cluster linkages appear to correspond to cognitive relationships at a higher level than research specialization (Jarneving, 2007).

\section{FINDINGS AND DISCUSSION}

In contrast to several previous studies, this research uses bibliometric analysis with 2030 journals related to e-learning.

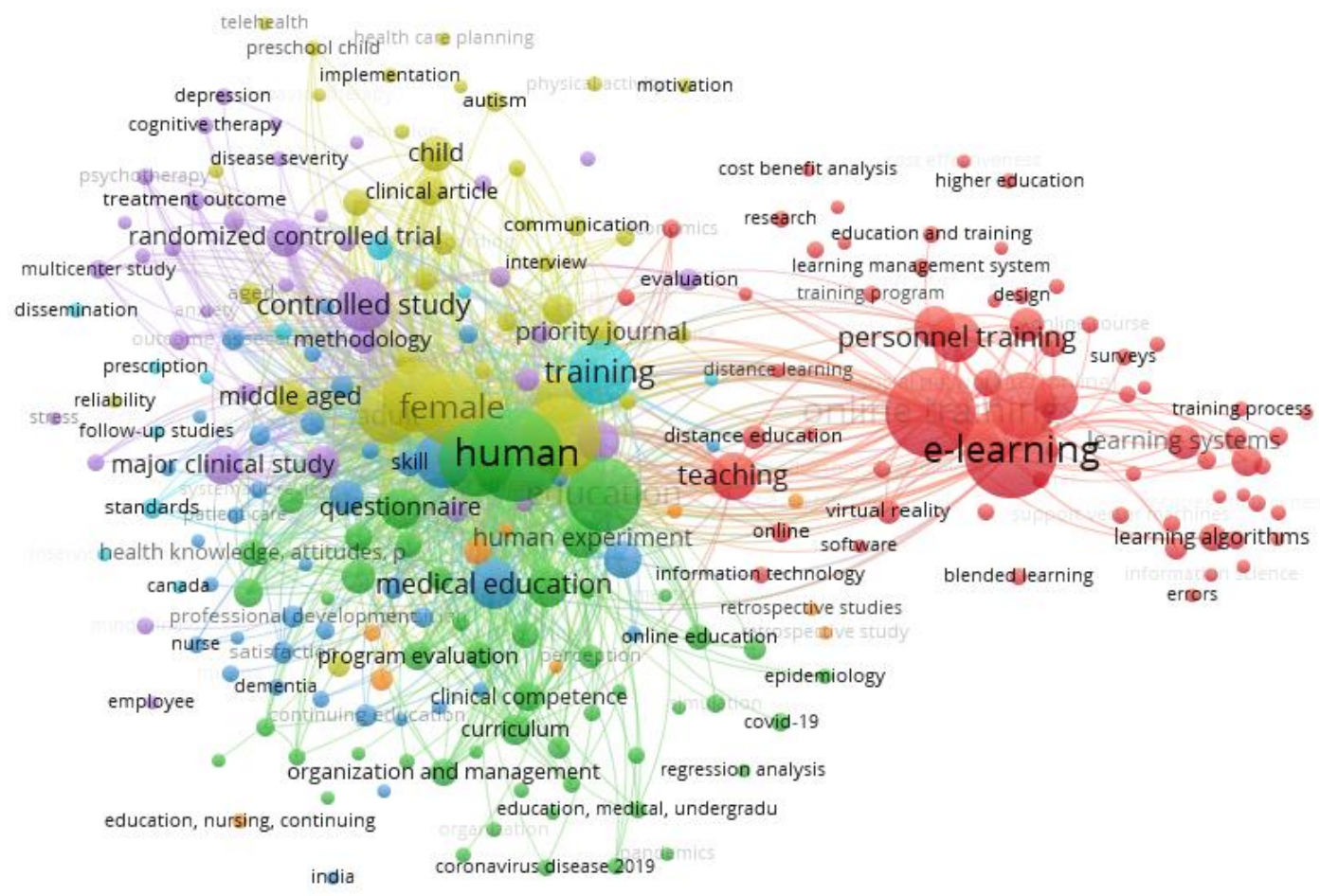

Figure 1. Network Visualization of E-Learning 
In the results of the visualization using the vos viewer using 2030 journals with the keyword elearning, an image is obtained as in Figure 1. above. In Figure 1, you can see that there are 5 different colors, namely yellow, green, blue, red, and purple, where the five colors represent the clusters formed. Each cluster has a point or center of the cluster. E-learning itself, which is described as a red cluster, is associated with 4 other clusters, namely female (yellow), human (green), training (blue), and controlled research (purple).

In Figure 1. the e-learning cluster does not appear to be too close to the other 4 clusters, which illustrates that the relationship between them is not too close, although they are still interconnected. On the other hand, the other four clusters appear to be almost unified because they are closely related to one another. E-learning itself is often used as a facility for conducting training, where there is a lot of research that there is more training about training to improve the quality of human beings, and moreover women so that there is equality. So the training targets are mostly middle aged women. It can also be seen from the network visualization that some of the links from the training itself are more related to health knowledge, skill improvement, and it is also found that the Indian word appears several times even though the link between nodules in Figure 1 looks far away.

\section{Cluster 1. E-learning as online training}

The concept of E-learning by utilizing internet technology has a lot of information and learning resources as well as facilities that can support learning such as forums, video tutorials, tests and others that can be used to discuss material and questions and answers between educators and education recipients, download and upload. teaching materials, and others (Yunianto, 2015). This can be seen in the red cluster, it can be seen that the word that often appears is online training. among them there are several things to do with training programs, surveys, learning systems, training processes, the software used and errors that occur during the e-learning process. There are also learning algorithms, because using the elearning method itself is not considered easy, because you have to understand several algorithms to make e-learning, as stated by Yunianto (2015) that e-learning itself has a high level of difficulty, including having to master programming languages such as PHP, HTML, JavaScript, MySQL, XML, CSS.

\section{Cluster 2. Controlled e-learning research}

This method has been going on for a long time until now in order to fulfill the main objectives of teaching and learning, but the concept used is facing several obstacles related to the limitations of the place, location and time of implementation with the increasing activity of educators and education recipients. The exchange of opinions on the learning system begins to show results in the process of exchanging knowledge or learning. The current learning process tends to prioritize teaching, content-based, one-way abstract and only for certain groups who can absorb what the teacher says (in this process teaching tends to be passive).

\section{Cluster 3. E-learning as a medium for skills improvement training}

E-learning is one of the media that is often used as a means of conducting training. This is because e-learning is considered capable of reaching even distant educational recipients. Even though the training is held abroad, anyone can receive the education that is delivered, as long as it is connected to the internet. Some trainings are also deliberately conducted using e-learning in the hope that both educators and education recipients can simultaneously learn and be literate about technology. 


\section{Cluster 4. Training for women through e-learning}

There are several obstacles for women in increasing their business. One of them is technological stuttering. As we know, technology continues to develop and telecommunications are increasingly innovating. With advances in information and communication technology today, the world no longer knows boundaries, distances, space and time. The internet has a big impact because it creates a new paradigm in entrepreneurship and doing business. One of the most prominent changes taking place in the business environment is online sales. Seeing this, several women's empowerment organizations have launched various trainings to help women improve their skills. E-learning is one of the main options for delivering the training so that most women receiving the training who also have other activities at home can also take part in the training without having to leave the house. In addition, the use of e-learning is also expected to be a separate exercise so that they are more familiar with the use of technology.

\section{Cluster 5. Humans as e-learning users}

Theoretically, the essence of education is life long learning. Therefore, education must be carried out from an early age through early childhood education programs to old age (seniors). Because education will always be needed by humans.

In the Covid-19 era, e-learning is the main choice so that the teaching and learning process continues, both at schools, campuses, and in training. Covid-19 is also one of the keywords that often appear from 2030 journals that are used, especially in journals found in 2019. Formal education that is held face-to-face or using conventional methods was forced to stop during Covid-19. The termination of the face-to-face learning process is one of the actions that the government has firmly established in an effort to break the chain of spreading COVID-19 through the world of education. The learning process is then carried out using the Distance Learning method (Winanti and Mas'udi, 2020).

\section{CONCLUSION}

Meanwhile Purbo and Hartanto (2002) requires three things that must be fulfilled in designing elearning, namely: simple, personal, and fast. A simple system will make it easy for students to take advantage of existing technology and facilities, with the convenience of the choice panel provided, it will reduce a lot of the introduction of the e-learning system itself, so that participants' learning time can take place efficiently for the learning process itself and not on learn to use its e-learning system. The personal requirement is that teachers can interact well like a teacher who communicates offline. Seeing the development of e-learning from time to time which continues to develop following the development of technology, it can be said that e-learning will become a learning system of the future. The reasons for effectiveness and flexibility will be the main reasons.

The e-learning system is absolutely necessary to anticipate the development of the times with the support of Information Technology where everything is heading towards the digital era (industrial revolution era 4.0), both the mechanisms and content used.

\section{RESEARCH PREPOSITIONS}

Based on the studies that have been done, the authors suggest further studies using different methods and databases. Further research is needed to be able to see the position of research if it is applied to the actual situation to solve an existing problem. For future researchers, the results of this research can be used as a comparison chart and reference for research, and as a consideration to further deepen further research by using case studies and using problems to solve or find solutions (research with experimental 
methods). Subsequent research can pay attention to the time of research so that the journals and references obtained are newer than those used in this research, namely 2016 to 2019. In addition, further research can expand the scope of research by adding the desired keywords. In addition, further research can also increase the number of journals used so that a visualization map is more complex than that shown by this research. However, researchers can also reduce the number of journals used so that they can get a more detailed visualization with a closer relationship between keywords. The use of other analytical methods and tools is strongly recommended, in addition to the addition of case studies.

\section{IMPLICATIONS}

\section{Academic Implications}

Academically, this research is expected to provide a good picture for future researchers to make this research the basis for further research. It is hoped that the next researchers can use this research as a reference and help map the references they need for future research. In addition, it is hoped that this research can help to increase knowledge and help anyone who needs to acquire new knowledge with the mapping presented in this research.

\section{Managerial Implications}

This research is expected to help managers to make decisions about e-learning to be carried out. Managers both in the world of education and companies need training which will inevitably be carried out using e-learning, especially during the Covid-19 pandemic which has not been resolved. In addition, technological developments also demand that both educators and education recipients be equally technologically literate, and the use of e-learning is felt to be able to help in a better condition. Training providers can also learn from this research if the provision of training using e-learning is more carried out and more helpful, especially to reach educational recipients in remote locations and also enable education recipients with busy time so that they can receive their education anywhere and anytime. they want it.

\section{REFERENCES}

Eck, N. J. V. 2011. Methodological Advances in Bibliometric Mapping of Science. Utrecht: Erasmus University Rotterdam.

Eck, N. J. V. and Waltman, L. 2010. Software survet: VOSviewer, A Computer Program for bibliometric mapping. Scientometrics, 84(2), pp. 523-538.

Ellegaard, O. and Wallin, J. A. 2015. The Bibliometric Analysis of Scholarly Production: How Great is the Impact? Scientometrics, 105(3).

Elsevier BV. 2015. Cara cepat dan mudah menggunakan Scopus.

Islamiyah, M. and Widayanti, L. Efektifitas Pemanfaatan E-Learning Berbasis Website Terhadap Hasil Belajar Mahasiswa STMIK Asia Malang pada Mata Kuliah Fisika Dasar. Jurnal Ilmiah Teknologi Informasi Asia, 10(1), pp 41-46.

Jarneving, B. 2007. Bibliographic Coupling and its Application to Research-Front and Other Core Documents. Journal of Informetrics, 1(4), 287-307.

Leydesdorff, L. and Rafols, I. 2011. Interactive Overlays: A New Method for Generating Global Journal Maps from Web-of-Science Data. Journal of Informetrics, 6(2).

Purbo, O.W. and Hartanto, A. A. 2002. Teknologi E-Learning Berbasis PHP dan MySQL: Merencakan dan Mengimplementasikan Sistem E-Learning. Jakarta: Gramedia. 
Rosenkrantz, A. B., Chung, R. and Duszak, R. 2019. Uncited Research Articles in Popular United States General Radiology Journals. Academic Radiology, 26(2), 282-285.

Suharyanto and Mailangkay, A. B. L. 2016. Penerapan E-Learning Sebagai Alat Bantu Mengajar dalam Dunia Pendidikan. Jurnal Ilmiah Widya 3(4).

Suyanto and Jihad, A. 2013. Menjadi Guru Profesional: Strategi Meningkatkan Kualifikasi dan Kualitas Guru di Era Global. Penerbit Erlangga.

Tamin, R. Penerapan Pembelajaran Elektronik Sebagai Strategi Pembelajaran Dosen dan Mahasiswa di Fakultas Ilmu Komputer Universitas Al Asyariah Mandar Provinsi Sulawesi Barat. Jurnal Pepatuzdo, 5(1), pp. 26-37

Tanudjaja, I. and Kow, G. Y. 2018. Exploring Bibliometric Mapping in NUS using BibExcel and VOSviewer, 1-9.

Tupan and Rachmawati, R. 2018. Analisis Bibliometrik Ilmu dan Teknologi Pangan: Publikasi Ilmiah di Negara - Negara ASEAN. Khizanah Al Hikmah Jurnal Ilmu Perpustakaan, Informasi dan Kearsipan, 6(1), pp. 26-40.

Tupan, Rahayu, R. N., Rachmawati, R. and Rahayu E. S. R. 2018. Analisis Bibliometrik Perkembangan Penelitian Bidang Ilmu Instrumentasi. Jurnal Dokumentasi dan Informasi, 39(2), 135-149.

Wibowo, S. A. and Roysa, M. 2018. Efektivitas Penggunaan Model Think Talk Write Berbantuan Media Komik Strip dalam Peningkatan Keterampilan Menulis Dialog Sederhana Siswa Kelas V SD 1 Tritis. KREDO: Jurnal Ilmiah Bahasa dan Sastra, 1(2).

Winanti, P. S. and Mas'udi, W. 2020. Tata Kelola Penanganan Covid-19 di Indonesia: Kajian Awal. Yogyakarta: UGM Digital Press.

World Bank. 2010. Education Public Expenditure Review. Forthcoming. World Bank Jakarta Office.

Yunianto, A. R. Implementasi E-Learning Berbasis Kelase Sebagai Sumber Belajar (Studi Kasus Siswa Kelas X Multimedia di SMK Bagimu Negeriku Semarang). Unnes Journal. 